\title{
ОРГАНІЗАЦІЙНО-ТАКТИЧНІ ЗАСАДИ ПРЕД'ЯВЛЕННЯ ОСОБИ ДЛЯ ВПІЗНАННЯ ЗА ЗОВНІШНІМИ ОЗНАКАМИ
}

Гриненко К. В.

Відповідно до норм чинного законодавства, даних слідчої та судової практики, а також наукових джерел у статmі досліджено організацію та тактику проведення пред'явлення особи для впізнання. Приділено увагу проведенню розглядуваної слідчої (розшукової) дії за анатомічними та функціональними ознаками особи. Розглянуто організаційно-тактичні засади, за яких проведення пред'явлення особи для впізнання за зовнішніми ознаками $\epsilon$ найбільш ефективним, та висловлено пропозиції щодо вдоскона лення норм Кримінального процесуального кодексу України.

Ключові слова: слідча (розшукова) дія, пред'явлення особи для впізнання за зовнішніми ознаками, пред'явлення особи для впізнання за голосом та ходою, організаційно-тактичні засади.

В соответствии с нормами действующего законодательства, данными следственной и судебной практики, а также научными источниками в статье исследованы организация и тактика проведения предъявления лица для опознания. Уделено внимание проведению рассматривае мого следственного (разыскного) действия с анатомиче скими и функциональными признаками лица. Рассмотрены организационно-тактические основы, при которых проведение предъявления лица для опознания по внешним признаками является наиболее эффективным, и сформулированы предложения по совершенствованию норм Уголовного процессуального кодекса Украины.

Ключевые слова: следственное (разыскное) действие, предъявление лица для опознания по внешним признакам лица, предъявление лица для опознания по голосу и походке, организационно-тактические основы.

Hrynenko K. V. Organizational and tactic principles of submission of a person for recognition based on appearance

The article carries the material about carrying out presentation a person for identification. Main attention is paid to the organization and tactics of this investigative (search) action. The research of theoretical issues and litigation.

The problem issues of the organizational and tactical principles of presentation a person for identification on external features were analyzed in this article, in accordance with the norms of the Criminal Procedural Code in Ukraine, other normative legal acts, data of investigative and judicial practice and scientific sources. At the beginning it deals with preparatory measures for conducting a certain investigative (search) action. The author focuses on interrogation procedure and explains that the investigator must find out the external features of the offender in detail. He dwells on example from the unified state register of court decisions to show how important it is to fixation the results after interrogation and presentation for identification.

Then the author passes on to questions of procedural order of carrying out presentation a person for identification by functional features. It is noted that this investigative (search) action can be carrying out when the crime has been committed in circumstances under which the victim is unable to see and remember certain functional features, that is grounds of voice, speech, gait. This investigative (search) action are crucial and difficult, so the investigator must order logopedic and biomechanical examinations.

The author makes a few critical remarks on norms of the Criminal Procedural Code in Ukraine, that why he proposes to change some positions in articles to better interpretation and understanding.

The summarize the author writes that implementation of organizational and tactical principles and compliance with scientific recommendations by investigators is a main condition for obtaining new evidence and effective investigation of crimes.

Key words: investigative (search) action, presentation person for identification by external features, presentation person for identification on grounds of voice and gait, organizational and tactical principles.

Постановка проблеми та їі актуальність. У результаті проведеного аналізу стану сучасної злочинності, з огляду на прогнози вчених-криміналістів на найближче майбутнє можна зробити висновок про постійне збільшення кількості висококваліфікованих злочинів. У зв'язку із цим постає проблема якісного збирання доказів. У діяльності слідчого під час досудового розслідування $\epsilon$ два головні напрями збирання доказової інформації у кримінальних провадженнях. Слідчий одержує інформацію об'єктивного характеру (речові докази) під час проведення слідчих (розшукових) дій, як-от огляд місця події, обшук, огляд речей та документів тощо, та інформацію суб'єктивного характеру (особистісні докази) під час проведення слідчих (розшукових) дій, як-от допит, пред'явлення для впізнання, слідчий експеримент тощо. Звісно, достатньою для доведення винуватості буде сукупність усіх доказів, однак дуже часто саме на показаннях свідків, потерпілих та підозрюваних слідчому вдається знайти істину у кримінальному провадженні.

Пред'явлення для впізнання в системі слідчих (розшукових) дій має особливе значення, хоча його проведення не $\epsilon$ обов'язковим. 3 огляду на слідчу практику, іноді пред'явлення особи для впізнання $\epsilon$ головною слідчою (розшуковою) дією, за результатами якої цілковито викривається особа, винна у кримінальному правопорушенні.

Проведення пред'явлення особи для впізнання за анатомічними та функціональними ознаками $\epsilon$ досить складним процесом. Буває так, що через низьку компетентність слідчого така слідча (розшукова) дія ігнорується, адже для їі проведення необхідно мати певні знання в інших сферах, наприклад у психології та логіці. Тому й наявні деякі організаційні та тактичні труднощі під час підготовки, проведення та фіксації даної слідчої (розшукової) дії. 
Аналіз останніх досліджень і публікацій. Зазначимо, що темі пред'явлення для впізнання присвячували свої наукові роботи такі вчені, як: Н.М. Ахтирська, Р.С. Бєлкін, Г.І. Кочаров, В.А. Колесник, В.О. Коновалова, В.Г. Лукашевич, Є.Д. Лук'янчиков, М.В. Салтевський, К.О. Чаплинський, Л.Д. Удалова, В.Ю. Шепітько й інші.

Організація та загальна тактика пред'явлення особи для впізнання досить повно висвітлена науковцями у криміналістичній літературі, а значущість проведених наукових досліджень безсумнівна. Дана слідча (розшукова) дія широко застосовується у правоохоронній практиці $i \epsilon$ поширеним способом збирання фактичних даних, однак питання організаційно-тактичних засад пред'явлення особи для впізнання за анатомічними та функціональними ознаками потребують детальнішого висвітлення.

Мета статті - проаналізувати тактику проведення пред'явлення особи для впізнання за зовнішнім виглядом з урахуванням сучасних потреб правоохоронної практики, розкрити особливості організації проведення даної слідчої (розшукової) дії, зокрема і процедуру збирання доказів відповідно до чинного законодавства.

Виклад основного матеріалу. Пред'явлення для впізнання - слідча дія, що полягає у пред'явленні свідкові чи іншій особі об'єктів, які вони спостерігали раніше, з метою встановлення їхньої тотожності або групової належності [1, с. 314].

Пред'явлення для впізнання проводиться в разі необхідності надати особі можливість впізнати серед людей чи речей, які їй пред'являються, ті, що вона бачила раніше, які стосуються вчиненого злочину. Процес учинення злочину супроводжується створенням різних слідів на предметах матеріального світу та в пам'яті людей. Завдання слідчого - виявити такі відображені сліди, використати їх для ідентифікації об'єктів, які брали участь у слідоутворенні. Пізнання події, що розслідується, здійснюється за матеріально зафіксованими відображеннями на предметах і за слідами в пам'яті людини. Тому під час пред'явлення для впізнання здійснюється криміналістична ідентифікація за ідеальними відображеннями. Отже, пред'явлення для впізнання - це один зі способів ототожнення об'єктів за ідеальними відображеннями (сліди пам'яті) у кримінальному провадженні [2, с. 7].

Метою цієї слідчої (розшукової) дії $\epsilon$ вирішення питання про тотожність або групову належність об'єкта, що пред'являється для впізнання, з тим, який особа сприймала в минулому. Досягнення зазначеної мети здійснюється через вирішення таких завдань, як: встановлення факту, чи бачила раніше особа, яка впізнає, об'єкт, який пред'являється для впізнання; якщо бачила, то коли і в яких умовах це відбувалося; які особливі ознаки об'єкта, який підлягає впізнанню, запам'ятала особа, яка впізнає, і чому саме ці ознаки вона запам'ятала тощо [3, с. 333-334].

Кримінальний процесуальний кодекс (далі - КПК) України виділяє проведення такої слідчої (розшукової) дії, як пред'явлення для впізнання особи (ст. 228), речей (ст. 229) та трупа (ст. 230). Пред'явлення особи для впізнання може проводитись за анатомічними (зовнішній вигляд і прикмети особи) та функціональними (голос, хода) ознаками (ч. 1 ч. 9 ст. 228 КПК).

Організаційно-тактичні засади до даної слідчої (розшукової) дії $\epsilon$ обов'язковою умовою іiі оптимального проведення. Пред'явлення особи для впізнання належить до найбільш важких дій щодо організації та підготовки, адже до їі проведення залучається велика кількість осіб.

Особливістю проведення пред'явлення особи для впізнання $\epsilon$ необхідність наявності юридичних та фактичних підстав. До юридичних підстав відносять:

наявність особи, яка буде впізнавати;

протокол іï допиту, у якому зафіксовано показання про прикмети й особливості особи, про обставини, за яких вона її сприймала;

особи, яка підлягає впізнанню;

зовнішньо схожих осіб (статисти), які будуть пред'являтися разом з особою впізнання.

До фактичних підстав належить наявність у слідчого даних, які дозволяють зробити висновок про необхідність, доцільність та можливість проведення цієї слідчої (розшукової) дії.

Зазвичай перед проведенням пред'явлення для впізнання проводиться низка інших слідчих (розшукових) дій, як-от допит, огляд, затримання тощо. Саме тому впізнання може проводитись як на початковому етапі розслідування, так і на подальших етапах.

Відповідно до ч. 1 ст. 228 КПК України, перед тим, як пред'явити особу для впізнання, слідчий, прокурор попередньо з'ясовує, чи може особа, яка впізнає, впізнати цю особу, onumyє їі про зовнішній вигляд і прикмети цієї особи, а також про обставини, за яких вона бачила цю особу, про що складає протокол. Якщо особа заявляє, що вона не може назвати прикмети, за якими впізнає особу, проте може впізнавати її за сукупністю ознак, у протоколі зазначається, за сукупністю яких саме ознак вона може впізнати особу. Забороняється попередньо показувати особі, яка впізнає, особу, яка повинна бути пред'явлена для впізнання, та надавати інші відомості про прикмети цієї особи.

Необхідно зазначити, що в ч. 1 ст. 174 Кримінально-процесуального кодексу України 1960 р. чітко й однозначно зазначено, що особу, якій треба пред'явити для впізнання певний об'єкт, спочатку треба допитати. У чинному КПК (ст. 228) допит як слідчу (розшукову) дію замінено на невідоме опитування. Незважаючи на те, що в подальшому за результатами опитування складають протокол, це не усуває невизначеності, на що звертає увагу О.В. Лускатов [4, с. 112]. Саме тому ми вважаємо, що було би доречним замінити в ч. 1 ст. 228 КПК слово «опитує» на «допитує», тим самим уникнути проблем щодо тлумачення та зрозумілості положення.

Можна погодитися 3 думкою $Є . Д$. Лук'янчикова й О.М. Моісєєва, які вважають, що попередній допит потерпілих (свідків) $\epsilon$ не тільки необхідним етапом у підготовці до пред'явлення для впізнання, а ще й обставиною, яка забезпечує ухвалення правильного рішення про доцільність проведення цієї слідчої дії, їі успішний перебіг, отримання належних результатів та їх наступну оцінку [5, с. 30].

Під час допиту слідчому потрібно якісно і максимально повно з'ясувати всі обставини злочинної події, а також отримати інформацію про загальні й характерні ознаки, риси та прикмети злочинця. До того ж слідчий має зважати на вік особи, яку допитують, та повною мірою оцінити проміжок часу, що минув від моменту сприйняття події. 
Необхідно зазначити, що в пам'яті людей $є$ значні індивідуальні відмінності стосовно швидкості і точності запам'ятовування інформації, iї тривалості збереження в пам'яті та готовності до їі відтворення. Зважаючи на всі чинники, слідчий повинен з'ясувати зовнішні ознаки людини (злочинця) за тією ж схемою, за якою складаються словесні портрети, водночас послуговуватися зрозумілою для суб'єкта впізнання мовою.

Завдяки дослідженням французького криміналіста А. Бертильона словесний портрет зазвичай складається з такого опису:

анатомічні ознаки, що визначають стать, вік, антропологічні риси зовнішності, зріст, статуру, будову тіла, голови, обличчя та його елементів тощо;

функціональні ознаки, що характеризують рухові та фізіологічні функції людини, як-от: осанка, хода, жестикуляція, міміка, мова, голос, манера поведінки або звички, артикуляція тощо;

особливі прикмети, тобто ті, що мають суттєву ідентифікаційну цінність. Вони бувають вроджені (родимі плями, родимки, наявність горба, заяча губа тощо), набуті (татуювання, шрами, бородавки або відсутність пальців тощо) та помітні прикмети - ті, які знаходяться на відкритих від одягу ділянках тіла і відразу запам'ятовуються;

супутні ознаки, що є прикметами одежі людини або предметів, що пов'язані з нею (окуляри, годинник, прикраси, брекети тощо), що можна поділити на виробничі (загальна назва і найменування, фасон, матеріал, розмір) та відображальні (ступінь і характер зносу, плями на тканині, особливі позначки).

Під час допиту слідчий активізує пам'ять того, хто впізнає, та допомагає йому пригадати якнайбільше ознак, що характеризують зовнішні прикмети злочинця. М.В. Салтевський і В.Г. Лукашевич зазначають, що слідчий спонукає особу спочатку пригадати необхідний уявний образ, а потім відтворити та передати слідчому дані про нього [6]. А науковець С.Г. Любічев уважає, що така підготовка слідчого полягає в «натаскуванні» потерпілих і свідків (підказка ознак, за якими вони мають впізнавати) і призводить до невірогідності впізнання [7, с. 35].

На нашу думку, попередній допит того, хто впізнає, $\epsilon$ важливим етапом перед проведенням пред'явлення особи для впізнання. Коли потерпілий або свідок не може описати ознаки особи, що підлягає впізнанню, однак стверджує, що зможе ії упізнати, то недоцільно відмовлятися від проведення даної слідчої (розшукової) дії. У такому разі потрібно безпосередньо перед упізнанням провести повторний допит, під час якого повно i детально отримати інформацію про індивідуальні ознаки особи або їх сукупність.

Варто зауважити, що наявна необхідність у доповненні ч. 7 ст. 223 КПК словами «під час проведення допиту перед пред'явленням для впізнання обов'язковим $€$ застосування безперервного відеозапису». Завдяки цій вимозі за допомогою застосування технічних засобів фіксування буде підтверджено незацікавленість слідчого в досудовому розслідуванні та повною мірою отримано інформацію про особу, яку можуть впізнати. До того ж на практиці мають місце непоодинокі порушення тактичних рекомендацій щодо заборони заздалегідь показувати тому, хто впізнає, об'єкт, який підлягає впізнанню (натурально, за відеозображенням або фотознімками), або повідомляти його ознаки. На наш погляд, застосування безперервного відеозапису було би доцільним.

Узагалі фіксація результатів проведення слідчих (розшукових) дій $\epsilon$ обов'язковою, зокрема у протоколі. А основним завданням слідчого під час допиту $\epsilon$ встановлення й обов'язкова фіксація зовнішніх ознак особи. Теж саме і під час безпосереднього проведення пред'явлення для впізнання: особа, яка впізнає, має пояснити, за якими ознаками вона впізнала, а слідчий має зафіксувати це у протоколі. Адже в разі невиконання таких вимог проведення даної слідчої (розшукової) дії, суд має право визнати докази недопустимими. Так, наприклад: «<...> 30 липня 2015 р., справа № 607/22453/ 13-к, Тернопільський міськрайонний суд задовольнив клопотання захисника ОСОБА_3 про визнання недопустимими доказами протоколів пред'явлення особи для впізнання від 14 вересня 2013 р., якими зафіксовано факт впізнання ОСОБА_4, ОСОБА_5, ОСОБА_6 та ОСОБА_7 особи під номером три, чотири, чотири та один відповідно. У клопотанні захисник вказав, що прокурор Г. надала суду докази, які, на ії думку, доводять вину ОСОБА_1 у вчиненні кримінального правопорушення стосовно ОСОБА_6. Ці докази він заперечує тому, що слідчі (розшукові) дії, а саме пред'явлення ОСОБА_1 для впізнання (cm. 228 КПК України) потерпілому ОСОБА_6 та свідкам ОСОБА_4, ОСОБА_5 та ОСОБА_7 були проведені із грубим порушенням кримінального процесуального законодавства, а його результати не можуть бути використані як докази відповідно до Конституції України та КПК України (cm. cm. 87, 88), оскільки вони є недопустимими. Зокрема, слідчий С. у жодному протоколі пред'явлення особи ОСОБА_1 для впізнання не зазначив відомості, які в обов'язковому порядку, згідно зі ст. 228 КПК України, повинні бути зазначені у змісті протоколів, тобто: прикмети особи, яку впізнають, опис їі зовнішнього вигляду, у чому вона одягнена, взута, їі тілобудова, якого кольору на голові волосся, стрижка тощо. У кожному із цих протоколів зазначено лише прізвище особи, що впізнає, дату, місяць i рік народження й адресу проживання, тим самим грубо порушено вимоги ст. 228 КПК України <...>» [8].

У даній ситуації слідчим порушено ч. 1 ст. 231 КПК, відповідно до якої про проведення пред'явлення для впізнання складається протокол, у якому докладно зазначаються ознаки, за якими особа впізнала особу, річ чи труп, або зазначається, за сукупністю яких саме ознак особа впізнала особу, річ чи труп.

За результатами допиту слідчий повинен визначити, яким способом у подальшому відбуватиметься пред'явлення особи для впізнання: за зовнішніми ознаками або за голосом, або за ходою. Адже досить часто трапляється, що в показаннях потерпілих і свідків містилися вказівки на те, що вони чули і запам'ятали голос злочинця $[9$, с. 70].

Варто наголосити на тому, що голос і мова людини сприймаються завжди в комплексі, тому що мова не може існувати поза голосом, яким вона передається. у систему зовнішніх ознак за методом «словесного портрета» науковцями включаються анатомічні ознаки, функціональні ознаки (постава, хода, жестикуляція, міміка, мова, манери), супутні елементи та їхні ознаки. Мова - це власне мовні особливості (вимова, говірка, 
акцент, уживання жарґонних слів тощо) і дані мовного механізму (темп, характер, особливості мови тощо). Голос характеризується стійкими ознаками незалежно від сказаного слова. Ці ознаки індивідуальні й характеризують особу, що дозволяє здійснити ідентифікацію. Голос має стійкі ознаки, його ідентифікація здійснюється навіть за навмисного спотворення, але за умови збільшення тривалості часу проголошення слів [10, с. 9].

У такому разі Г.І. Кочаров розрізняє три варіанти: а) коли людина, голос якої допитуваний чув у зв'язку з подією злочину, допитуваному до цієї події відома не була; б) коли допитуваний стверджує, що він знайомий з особою, голос якої він чув у зв'язку з подією злочину, i вказує на неї, але названа допитуваним особа заперечує це знайомство; в) коли допитуваний заявляє, що особа, голос якої він чув у зв'язку з подією злочину, йому добре знайома, але прізвище й ім'я її не знає чи називає неправильно, або інакше, ніж називає особа, на яку вказує допитуваний [11, с. 8-9]. Крім того, впізнання особи за ознаками голосу та мовлення необхідно проводити і тоді, коли зовнішність розшукуваної особи змінена і не можуть бути використані з певних причин інші фізичні особливості [11, с. 34]

На підставі проведеного опитування працівників слідчих підрозділів К.О. Чаплинський зазначає, що впізнання за голосом і особливостями мови відбувається лише в $1 \%$ справ, а у $18 \%$ проведення такої процедури було очевидною необхідністю, але під час досудового розслідування не робилося. [12, с. 241].

Важливість детального дослідження пред'явлення для впізнання за голосом полягає в тому, що така слідча (розшукова) дія $\epsilon$ унікальною і ніколи не дублюється, отже, ефективність та доказове значення результатів впізнання значною мірою залежать від якості проведення слідчим організаційно-підготовчих заходів.

Відповідно до ч. 9 ст. 228 КПК, впізнання за голосом повинно здійснюватися поза візуальним контактом між особою, що впізнає, та особами, які пред'явлені для впізнання. Тобто ця частина ст. 228 КПК виключає можливість задіяти зорове сприйняття, хоча в ч. 1 цієї статті зазначено, що до пред'явлення особи для впізнання слідчий, прокурор попередньо з'ясовує «<...> обставини, за яких вона бачила цю особу». Тому, на нашу думку, було би слушним замінити слово «бачила» на слово «сприймала», що не буде суперечити частинам статті.

Практичним працівникам надані рекомендації щодо проведення допиту особи, яка буде впізнавати, про необхідність детального з'ясування специфічних ознак голосу та мови особи, яка підлягає впізнанню. До таких характерних ознак у запропонованій методиці віднесено: тип голосу за висотою, тембр голосу, гучність, вид мови, стиль, словниковий запас, дикцію, темп, форму викладення мовного повідомлення, діалект, акцент, патологію мови, сталі фразеологічні звороти, діалектизми, звукові звички, сучасні слова іноземного походження, наголос у словах, слова-паразити, особливі прикмети голосу та мови тощо [13, с. 18].

Особливістю $\epsilon$ необхідність допиту особи, яка пред'являється для впізнання, що зумовлена потребою слідчого в безпосередньому сприйнятті ознак голосу та мовлення цієї особи, їі індивідуальних якостей. Відсутність у слідчого особисто сприйнятої інформації про відповідну особу може призвести згодом до ускладнень у підготовці, проведенні пред'явлення особи для впі- знання, а згодом і в оцінці отриманих результатів. Крім того, якщо слідчий не матиме особисто сприйнятих ознак голосу та мовлення особи, що перевіряється, він не зможе підібрати статистів, зі схлжими голосами.

Щоб отримати більш точні дані про ознаки об'єктів, які будуть пред'являтися для впізнання, та забезпечити достовірність його результатів, можна звернутися по допомогу до фахівця у відповідній галузі знань. А коли виникають сумніви щодо об'єктивності результатів впізнання за голосом і мовою, слідчий може призначити логопедичну експертизу, висновок якої допоможе уникнути можливості посилання обвинуваченого на суб'єктивний характер сприйняття особою, яка впізнавала його за голосом і мовю.

Щодо пред'явлення особи для впізнання за ходою необхідно зазначити, що дана слідча (розшукова) дія у практичній діяльності трапляється ще рідше, аніж впізнання за голосом і мовою.

Це пояснюється тим, що віднайти характерні ознаки ходи людини, відрізнити одну людину від іншої за ходою вкрай складно. Зазвичай людині вкрай складно описати словами ходу іншої людини. Тільки яскраво виражені особливості (кульгавість, сильне розгойдування корпусу тіла, розмахування руками) фіксуються в пам'яті людини і в подальшому відтворюються в показаннях [14, с. 237].

Тому 3 метою забезпечення результативності пред'явлення для впізнання за ходою, гарантування об'єктивності отриманих результатів і виключення сумнівів щодо правильності ототожнення людини слідчому під час підготовки до допиту треба чітко визначити ознаки, за якими здійснюватиметься процес впізнання. Виділяють такі основні ознаки ходи: за темпом; за рівномірністю, симетричністю рухів; за ступенем підняття стоп; за положенням, рухом тулуба, голови, плечей, рук та іншими особливостями. Наскільки повно будуть описані у протоколі допиту ознаки, за якими особа буде впізнавати, настільки достовірними будуть результати слідчої (розшукової) дії.

Коли особливості ходи особи, яка пред'являється для впізнання, малопомітні, свідкам, потерпілим надто складно їх описати. Тому не зовсім зрозуміло, чи наявні вони в особи, яка буде пред'являтися для впізнання. у такому разі може суттєво допомогти використання спеціальних знань у сфері біомеханіки. Коли впізнання проводиться тільки за ходою, є сумніви в достовірності результатів пред'явлення для впізнання, слідчому доцільно призначати біомеханічну експертизу.

Висновки. Ґрунтуючись на аналізі досліджень криміналістів з організації і тактики проведення такої слідчої (розшукової) дії, як пред'явлення особи для впізнання, доходимо висновку, що дана процедура потребує наукового розроблення. Пред'явлення особи для впізнання за зовнішніми ознаками $є$ слідчою (розшуковою) дією, яка широко та досить часто застосовується на досудовому розслідуванні, однак практичні працівники нерідко припускаються помилок під час організації та процедури проведення впізнання. Пред'явлення особи для впізнання за функціональними ознаками, а саме за голосом та ходою, безумовно, потребує розробки рекомендацій з організаційно-тактичного забезпечення проведення даної слідчої (розшукової) дії.

Серед організаційно-тактичних заходів найбільш важливий попередній допит особи, яка впізнає, 
3 детальним описом особи (злочинця) і обов'язковою фіксацією результатів проведення слідчих (розшукових) дій. Докладне дотримання зазначених умов дозволяє провести пред'явлення особи для впізнання максимально ефективно. Крім того, наявність прогалин або неточностей у КПК інколи призводить до неоднакового застосування відповідних норм, що також може поставити під сумнів можливість використання отриманих результатів, саме тому наведено пропозиції щодо восконалення норм КПК України.

Отже, здійснення організаційно-тактичних засад і дотримання наукових рекомендації слідчим $€$ обов'язковою умовою отримання нових доказів під час розслідування злочинів.

\section{Література}

1. Криміналістика : підручник для студентів юридичних спеціальностей вищих закладів освіти / В.М. Глібко та ін. ; за ред. В.Ю. Шепітька. Київ, 2001. 684 с.

2. Лукьянчиков Е.Д. Криминалистическая идентификация объектов по следам памяти : учебное пособие. Донецк : Академия, 1998. 112 с.

3. Чаплинський К.О. Тактичні основи забезпечення досудового розслідування : дис. ... докт. юрид. наук: 12.00.09. Дніпропетровськ, 2011. 570 с.

4. Лускатов О.В. Проблемні аспекти повторного пред'явлення для впізнання. Актуальні питання теоріі і практики криміналістичної науки : матеріали Всеукраїнської науково-практичної конференції, присвяченої 50-річчю кафедри криміналістики та судової медицини Національної академії внутрішніх справ, 23 січня 2015 р. Київ : Видавничий дім «Гельветика», 2015. С. 111-114.

\section{Організаційно-правові аспекти досудового слідства}

5. Лук'янчиков Є.Д., Моісєєв О.М. Пред'явлення для впізнання : навчальний посібник. Макіївка, 1998. 121 с.

6. Салтевский М.В., Лукашевич В.Г. Проблемы классификации источников информации и следственных действий в криминалистической тактике. Криминалистика и судебная экспертиза. 1984. № 29. С. 29-35.

7. Любичев С.Г. Этические основы следственной тактики. Москва, 1980. 96 с.

8. Єдиний державний реєстр судових рішень України : офіційний сайт. URL: http: // reyestr.court.gov.ua/.

9. Бурыка Д.А., Самошина З.Г. О видах и формах предъявления для опознания. Вестник криминалистики. 2005. № 3 (15). С. 62-71.

10. Пред'явлення особи для впізнання за ознаками голосу та мовлення під час досудового розслідування : методичні рекомендації / М.П. Климчук та ін. Київ, 2019. 60 c.

11. Кочаров Г.И. Опознание на предварительном следствии. Москва, 1955. 84 с.

12. Чаплинський К.О. Особливості пред'явлення для впізнання за голосом, особливостями мови і фонограмою. Право і суспільство. Дніпро, 2017. № 1. С. 240-245.

13. Методичні рекомендації щодо пред'явлення для впізнання на попередньому слідстві 5483 / Головне слідче управління МВС України. Київ, 2001. 32 с.

14. Марченко А.Б. Тактичні особливості пред'явлення для впізнання за ознаками ходи. Вісник Луганського державного університету внутрішніх справ імені Е.О. Дідоренка. 2010. № 4. С. 236-241.

Гриненко К. В., ад’юнкт кафедри криміналістики та судової медицини Національної академії внутрішніх справ 